\title{
Reliability analysis of the aircrafts normal braking system
}

\author{
Agung Premono ${ }^{1, *}$ and Martin Danang Laksono ${ }^{1}$ \\ ${ }^{1}$ Mechanical Engineering Department, Faculty of Engineering, State University of Jakarta, Jakarta, Indonesia
}

\begin{abstract}
An identified component of Airbus A-330 aircraft which should be maintained properly is the normal braking system. The objectives of this study are to: (1) identify the critical component of the normal braking system; and (2) determine the optimal replacement time interval of replacement of the normal braking system component. This study is conducted in Garuda Maintenance Facility Aero Asia company. Primary data in this study are the components replacement data of normal braking system in period January 2015 - January 2017. The life distribution such as Mean Time to Failure (MTTF), reliability, probability density function, cumulative distribution function, and failure rate are obtained by the Weibull++ software. Results show that the critical component of the normal braking system is the brake unit assembly. Meanwhile, the life distribution analysis show that the reliability of importance value of the normal breaking system IR is 74.07 percent which occurs at MMTF and system reliability are 4365.5 hours and 55.58 percent, respectively. These values indicate that optimal replacement time interval of the Brake Unit Assembly is 5599.7 hours.
\end{abstract}

\section{INTRODUCTION}

Aeroplane safety in flight is under the influence of many factors. One of these factors is braking safety while the aircraft is landed. Several plane crashes are caused by failure of the braking system[1]. In order to reduce failure of the braking system, monitoring and checking of the system are required. These activities involve analysis of the pilot report, delay report and maintenance report. Pilot report is the data from the pilot while an error occurs in flight such as taxing, take off, flight, and landing. Maintenance report obtained by maintenance operator while the aircraft is repaired. Delay report is the incident flight report which causes airplane delay. Therefore, these data are obtained from the real flight conditions.

Research of the aircrafts braking system has been carried out by previous researcher in limited quantities. Aircraft braking system has explained by Shruti and Shreya N[2]. Meanwhile, reliability analysis of the aircraft braking system was studied by Al-Garni et.al[3] and performed in Boeing 737 series aircraft. This research has not been determined the optimum time for critical component replacement. In this present research, reliability of the normal braking system of the Airbus A330 series aircraft is investigated. Furthermore, optimum time for critical component replacement is determined. This research is performed based on the damage data of the braking system during January 2015 - January 2017 in Garuda Maintenance Facility AeroAsia. In this period, the damage is dominated by the normal breaking system.

\section{LITERATURE REVIEW}

\subsection{The Norml Braking System in The Aircraft}

Airbus A-330 series has main landing gear with eight wheels. Braking system in this aircraft is located in each main landing gear in each wheel. The brake is made of carbon multi-gear which is equipped with 14 piston cylinders. This piston is driven by two hydraulic systems, hydraulic green and blue. Flight by wire control system technology is adopted in this aircraft. Main component of the braking system consists of: (1) brake unit assembly, brake pedal transmitter, Brakes and Steering Control Unit (BSCU), automatic selector valve, normal brake selector, servo valve, return accumulators, and green manifold assembly.

Work principle of normal braking is started from the first input by stepping the brake pedal or by pressing the landing gear push button at the cockpit panel. Signal from the input is passed to BSCU. Furthermore, the signal is ordering to open the normal selector valve. This valve distributes the hydraulic fluid from the manifold to automatic selector valve. Fluid flows to normal servo valve, then pushing the piston to activate the brake[4].

\subsection{Reliability of The Normal Braking System}

Reliability is the probability of success or the probability that the system will perform its intended function under specified design limits[5]. Reliability distribution function is required to estimate the reliability value of component. Several methods are used to determine the reliability distribution function. These are: (1) Weibull distribution; (2) Normal distribution; (3) Lognormal distribution; and (4) Exponential distribution.

* Corresponding author: agung-premono@unj.ac.id 
All methods have similarity parameters -- probability density function, cumulative distribution function, reliability function, failure rate function, and MTTF -- to determine the reliability function. In this paper, only Weibull distribution is presented.

The probability density function is[6]:

$$
f(t)=\frac{\beta(t-\gamma)^{\beta-1}}{\theta^{\beta}} e^{-\left(\frac{t-\gamma}{\theta}\right)^{\beta}} \quad t \geq \gamma \geq 0
$$

where $\theta$ and $\beta$ are known as the scale and shape parameters, respectively, and $\gamma$ is known as the location parameter.

The reliability function $\mathrm{R}(\mathrm{t})$ is

$$
R(t)=e^{-\left(\frac{t-\gamma}{\theta}\right)^{\beta}} \text { for } t>\gamma>0, \beta>0, \theta>0
$$

Hence, the failure rate function (h) is

$$
h(t)=\frac{\beta(t-\gamma)^{\beta-1}}{\theta^{\beta}} \quad t>\gamma>0, \beta>0, \theta>0
$$

Mean Time to Failuer (MTTF) is

$$
M T T F=\theta \Gamma\left(\frac{1+\beta}{\beta}\right)
$$

where value of $\Gamma\left(\frac{1+\beta}{\beta}\right)$ is obtained from table of $\Gamma(x)$ Gamma function.

Reliability of Importance $\left(\mathrm{I}_{\mathrm{i}}^{\mathrm{B}}\right)$ of component $\mathrm{i}$ in the component system $\mathrm{n}$ is predicted by Birnbaum equation as follow:

$$
I_{i}^{B}=\frac{\partial R_{s}[R(t)]}{\partial R_{i}(t)}
$$

where $\mathrm{Rs}$ is reliability value of system and $\mathrm{Ri}$ is reliability value of component

\section{METHODOLOGY}

The damage data of the braking system during January 2015 - January 2017 for Airbus A-330 series are obtained in Garuda Maintenance Facility AeroAsia Co. Data is obtained from the component removal data which is caused by unscheduled maintenance. These data are collected from pilot report, maintenance report, and delay report. Fault tree analysis is used to analyse the data. The life distribution such as Mean Time to Failure (MTTF), reliability, probability density function, cumulative distribution function, and failure rate are obtained by the Weibull++ software. Several steps is conducted sequentially to obtained the results. There are: (1) obtaining the Time to Failure (TTF) value from the replacement component data; (2) Estimating the Maximum Likelihood Estimate (MLE) for each component.; (3) Calculating MTTF of each component in the normal breaking system; (4) Calculating reliability of each component in the normal breaking system; (5) Creating a Reliability Block Diagram (RBD); (6) Determining Reliability Importance; and (7) Determining the optimal interval schedule of critical component.

\section{RESULTS AND DISCUSSION}

Unscheduled maintenance data which is obtained from the problem beyond the schedule maintenance is recorded as the replacement component data in this research. Distribution component of the normal braking system is determined by Reliasoft Weibull ++ 9.0 software using Maximum Likelihood Estimation (MLE) method[7]. Weibull, Normal, Lognormal, and Exponential are calculated. Results show suitable method to evaluate the reliability function and parameter distribution for each component with appropriate with TTF distribution data. Suitable method and parameter for this calculation are summarized in Table 1.

Table 1 Suitable Method and Parameter for Each Component of Normal Braking System

\begin{tabular}{|l|l|l|l|}
\hline \multicolumn{1}{|c|}{ Component } & \multicolumn{1}{|c|}{$\begin{array}{r}\text { Suitable } \\
\text { Method }\end{array}$} & \multicolumn{2}{|c|}{ Parameter } \\
\hline $\begin{array}{l}\text { Brake Unit } \\
\text { Assembly }\end{array}$ & 2P-Weibull & $\mathrm{b}=3,5287$ & $\theta=6216,95$ \\
\hline $\begin{array}{l}\text { Return } \\
\text { Accumulator, } \\
\text { Normal Brake }\end{array}$ & 2P-Weibull & $\mathrm{b}=1.580395$ & $\theta=12410.21$ \\
\hline $\begin{array}{l}\text { Servo valve, } \\
\text { Normal Brake }\end{array}$ & Normal & $\mu=7832,918$ & $\sigma=3586,578$ \\
\hline $\begin{array}{l}\text { Brake \& } \\
\text { Steering } \\
\begin{array}{l}\text { Control Unit } \\
\text { (BSCU) }\end{array}\end{array}$ & 2P-Weibull & $\mathrm{b}=2,019235$ & $\theta=12327,96$ \\
\hline $\begin{array}{l}\text { Automatic } \\
\text { Selector Valve }\end{array}$ & Normal & $\mu=9638.4$ & $\sigma=2709.16$ \\
\hline $\begin{array}{l}\text { Transmitter } \\
\text { Pedal Brake }\end{array}$ & 2P-Weibull & $\mathrm{b}=5.247662$ & $\theta=9759.277$ \\
\hline
\end{tabular}

Table 1 show that the brake unit assembly, return accumulator, BSCU, and transmitter pedal brake are several critical components in the normal braking system. These data are used to calculate MTTF which refer to Eq. (4). MTTF value of each component in the normal braking system is shown in table 2 . 
Table 2. MTTF value and distribution function of each component in the normal braking system

\begin{tabular}{|c|c|c|c|c|c|}
\hline \multirow{2}{*}{ Component } & \multicolumn{4}{|c|}{$\mathrm{t}=\mathbf{M T T F}$} & \multirow{2}{*}{$\begin{array}{l}\text { MTTF } \\
\text { (hours) }\end{array}$} \\
\hline & $\mathbf{f}(\mathbf{t})$ & $\mathbf{F}(\mathbf{t})$ & $R(t)$ & $h(t)$ & \\
\hline $\begin{array}{l}\text { Brake Unit } \\
\text { Assembly }\end{array}$ & 0.00021 & 0.49 & $50.1 \%$ & 0.000435 & 5599,73 \\
\hline $\begin{array}{l}\text { Return } \\
\text { Accumulator }\end{array}$ & $5.147 \mathrm{E}-05$ & 0.56 & $43.0 \%$ & 0.000119 & 11139.65 \\
\hline Servo valve & 0.00011 & 0.50 & $50 \%$ & 0.000222 & 7832.918 \\
\hline $\begin{array}{l}\text { Brake } \\
\text { Steering } \\
\text { Control Unit } \\
\text { (BSCU) }\end{array}$ & $6.61 \mathrm{E}-05$ & 0.54 & $45.7 \%$ & 0.000145 & 10921.96 \\
\hline $\begin{array}{l}\text { Automatic } \\
\text { Selector } \\
\text { Valve }\end{array}$ & 0.000147 & 0.5 & $50 \%$ & 0.000294 & 9638.4 \\
\hline $\begin{array}{l}\text { Pedal } \\
\text { Transmitter } \\
\text { Brake }\end{array}$ & $6.998 \mathrm{E}-05$ & 0.41 & $58.9 \%$ & 0.000118 & 8985.63 \\
\hline
\end{tabular}

Table 2 show that the lowest of MTTF value occurs in the Brake Unit Assembly. Reliability importance is used to carried out the most critical component of the normal breaking system. The reliability importance value of each component is determined by Eq. (2). Reliability importance value of each component in the normal braking system is summarized in Table 3 .

Table 3 Reliability importance value of each component in the normal breaking system

\begin{tabular}{|c|c|c|}
\hline \multirow{2}{*}{ Component } & \multirow{2}{*}{$\begin{array}{l}\text { Suitable } \\
\text { Method }\end{array}$} & t=MTTFs \\
\cline { 3 - 3 } & 2P-Weibull & R(t) \\
\hline Brake Unit Assembly & 2P-Weibull & $82.04 \%$ \\
\hline Return Accumulator & Normal & $83.32 \%$ \\
\hline Servo valve & 2P-Weibull & $88.43 \%$ \\
\hline $\begin{array}{c}\text { Brake Steering Control } \\
\text { Unit (BSCU) }\end{array}$ & Normal & $97.42 \%$ \\
\hline Automatic Selector Valve & 2P-Weibull & $98.54 \%$ \\
\hline Pedal Transmitter & \multicolumn{2}{|c}{} \\
\hline
\end{tabular}

The reliability of the normal braking system which has calculated by Reliasoft Weibull ++9.0 is $55.58 \%$. Therefore, the reliability importance index for each component have summarized in Table 4. These values are calculated by Eq. (5). Table 4 shows that the most critical component in the normal braking system is the brake unit assembly. This conclusion refers to the biggest of the reliability importance index. Hence, the most priority component that should be prioritized on the preventive maintenance is the Brake Unit Assembly. The optimal replacement time interval of replacement of the normal braking system component -- the brake unit assembly - is 5599.7 hours. This value refers to table 2 .
Table 4 Reliability importance index of each component in the normal breaking system

\begin{tabular}{|c|c|c|}
\hline Component & $\begin{array}{c}\text { Suitable } \\
\text { Method }\end{array}$ & I Ri $=\mathbf{R s} / \mathbf{R}(\mathbf{t})$ \\
\hline Brake Unit Assembly & 2P-Weibull & 74.07 \\
\hline Return Accumulator & 2P-Weibull & 67,33 \\
\hline Servo valve & Normal & 66.71 \\
\hline $\begin{array}{c}\text { Brake Steering Control } \\
\text { Unit (BSCU) }\end{array}$ & 2P-Weibull & 62.85 \\
\hline Automatic Selector Valve & Normal & 57.05 \\
\hline Pedal Transmitter Brake & 2P-Weibull & 56.40 \\
\hline
\end{tabular}

\section{CONCLUSION}

From the calculation results, it may be concluded that the most critical component of the aircraft normal braking system is the brake unit assembly. This conclusion is based on the reliability importance index 74.07 which is obtained at yaitu $\beta=3,528781, \theta=$ $6216,95, \mathrm{R}(\mathrm{t}) 75.04 \%$, and $\mathrm{R}(\mathrm{s})$ is $55.58 \%$. The optimal replacement time interval of replacement of the this component is 5599.7 hours.

\section{References}

[1] http://www.telegraph.co.uk/news/worldnews/europe/r ussia/9771664/Faulty-brake-system-blamed-forMoscow-plane-crash.html

[2]Shruti N and Shreya N, Aircraft Braking System, IJRMET Vol. 4, Issue 1, Nov 2013 - April 2014.

[3]Al-Garni A.Z, et.al, Reliability Analysis of Aeroplane Brakes, Qual. Reliab. Engng. Int. 15: 143-150 (1999)

[4]Airbus, Aircraft Maintenance Manual type A330 halaman 18 Figure 32-42-27-991-00900-00-B A

[5]Elsayed, A. Elsayed, Reliability Engineering $2^{\text {nd }}$ Edition, New Jersey, John Wiley \& Sons, INC (2012)

[6]Modarres, M., Kaminsky, M. \& Krivtsov,V.. Reliability Engineering and Risk Analysis : A Partical Guide $2^{\text {nd }}$ Edition, Boca Raton: CRC Press Taylor \& Francis Group, (2010)

[7]Reliasoft Weibul++ Life Data Analysis Software Tool, http://www.reliasoft.com/Weibull/index.htm. 